\title{
A Deadly Pair: Conflicts of Interest Between Death Investigators and Prosecutors
}

\author{
IRA P. ROBBINS*
}

As an inevitable fact of life, death is a mysterious specter looming over us as we move through the world. It consumes our literature, religions, and social dialogues - the death of a prominent figure can change policies and perceptions about our approaches to many problems. Given death's significance, it is reasonable to try to understand causes of death generally, as well as on a case-by-case basis. While scholars and mourners attempt to answer the philosophical questions about death, the practical and technical questions are typically answered by death investigators. Death investigators attempt to decipher the circumstances surrounding suspicious and unexplained deaths to provide solace to family members and information to law enforcement services to help them determine whether further investigative steps are necessary. But while the answers provided by death investigators may provide some direction, in many ways the death investigation system actually inhibits the pursuit of justice.

The current death investigation system creates conflicts of interest between death investigators and prosecutors. Death investigators and prosecutors are often organized under the same governmental structure or even within the same offices. This close association between the two systems results in patterns of relationships that disadvantage defense teams and prevent equal access to death investigation resources. This Article explores the ways in which the death investigation system is constrained by prosecutorial discretion and the institutional proximity of the two offices. This Article also examines how this relationship constitutes a failure of the justice system in the form of both overt and discreet conflicts of interest between death investigators and prosecutors. The effects of these conflicts can be remedied, however. The Article thus provides recommendations to enhance the accuracy and integrity of the death investigation process.

* Barnard T. Welsh Scholar and Professor of Law and Justice, American University, Washington College of Law. A.B. University of Pennsylvania; J.D. Harvard University. I am more than ordinarily grateful to my superb and indispensable research assistantsJoseph Briscar, Carly Brown, Lauren Goldschmidt, Hannah Nallo, Belgin Palaz, Catherine Potter, and Deirdre Smith - whom I consider to be my colleagues and my friends, and to Dean Camille Nelson, for providing summer financial support. Copyright (C) 2018 by Ira P. Robbins. All rights reserved. 


\section{TABLE OF CONTENTS}

I. INTRODUCTION

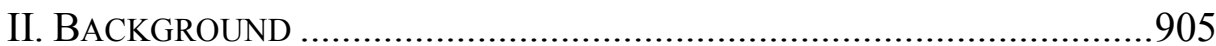

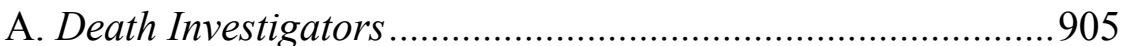

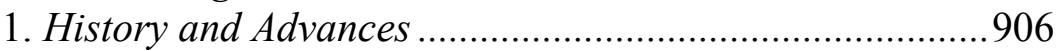

2. Modern Day Death Investigation Systems........................908

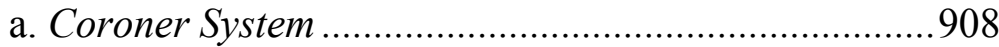

b. Medical Examiner System ............................................909

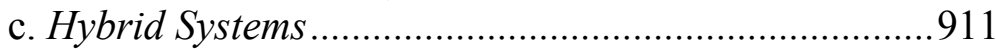

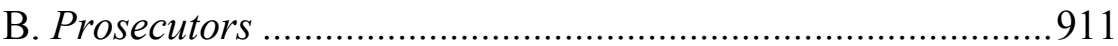

1. The Modern Prosecutor's Role in the Death

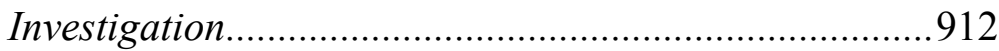

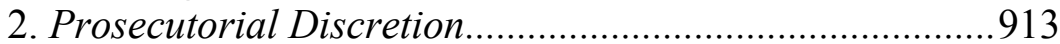

3. Constraints on Prosecutors .............................................914

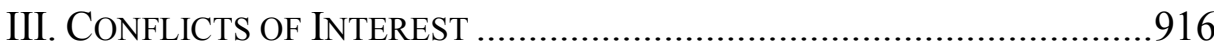

A. Overt and Apparent Conflicts of Interest ..............................917

1. Allowing the Prosecutor to Serve as the Coroner

Creates an Overt Conflict of Interest..............................918

2. One Party or Both Parties Knowingly Act Due to an

Obvious Conflict of Interest ...........................................9920

B. Discreet and Non-Obvious Conflicts of Interest ....................924

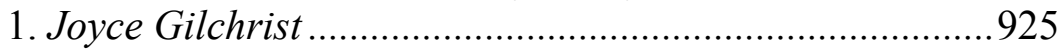

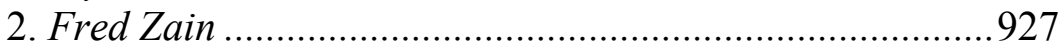

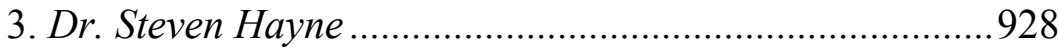

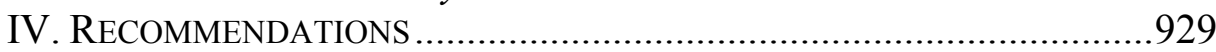

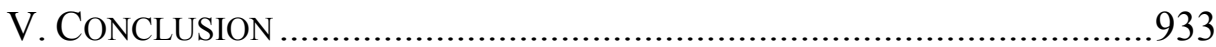

\section{INTRODUCTION}

In the middle of the 2016 presidential campaign, an unexpected occurrence changed the landscape of American jurisprudence: Supreme Court Justice Antonin Scalia was found dead in his sleep. ${ }^{1}$ Justice Scalia died at a West Texas ranch while on a hunting trip with friends. ${ }^{2}$ His death sparked a political battle for control over the Supreme Court, with the United States Senate refusing to conduct hearings on a replacement justice with eleven

${ }^{1}$ See Amy Brittain \& Sari Horwitz, Texas Sheriff's Report Reveals More Details on Supreme Court Justice Scalia's Death, WASH. PosT (Feb. 23, 2016), https://www.washing tonpost.com/world/national-security/texas-sheriff-releases-report-on-supreme-court-justice -scalias-death/2016/02/23/8c0bdb0c-da82-11e5-891a4ed04f4213e8_story.html [https://perma.cc/VN3K-N34P] (reporting that Justice Scalia died on February 13, 2016).

${ }^{2}$ See id. 
months left in President Obama's last term. ${ }^{3}$ While many people knew the political ramifications of Justice Scalia's death, few people focused on the procedural problems related to how his death was handled. ${ }^{4}$

Justice Scalia was discovered in bed with a pillow over his head. His breathing apparatus had been switched off, and his head was elevated on three pillows. ${ }^{5}$ Despite the curious scene, the justice of the peace declared Scalia dead from natural causes; he issued this finding by telephone without having any official examine the body, let alone perform an autopsy. ${ }^{6}$ While this process led to numerous conspiracy theories and paranoia, the investigation surrounding Justice Scalia's death sheds light on the sorry state of death investigations in the United States. There is no federal framework governing death investigations or the qualifications of death investigators. Thus, local officials in small counties are left with the power to make sometimes momentous decisions that have far-reaching impact. Because Justice Scalia died in Texas, state law governed, giving a small town judge and a justice of the peace sole power to determine the cause of Justice Scalia's death without an autopsy. ${ }^{7}$

As in Justice Scalia's case, death investigators are generally charged with classifying suspicious, unexplained, or mysterious deaths. The death

${ }^{3}$ See Nina Totenberg, 170-Plus Days and Counting: GOP Unlikely to End Supreme Court Blockade Soon, NPR (Sept. 6, 2016), http://www.npr.org/2016/09/06/492857860/17 3-days-and-counting-gop-unlikely-to-end-blockade-on-garland-nomination-soon

[https://perma.cc/GQP6-XP77] (explaining that Senate Republicans refused to hold hearings, take votes, or take any action at all to confirm President Obama's Supreme Court nominee, Merrick Garland, to fill Justice Scalia's vacant Supreme Court seat). After the election of Donald Trump to the presidency, he rescinded the Garland nomination, and then nominated Neil Gorsuch to fill Justice Scalia's seat; the Senate later confirmed Gorsuch. See Ariane de Vogue \& Dan Berman, Neil Gorsuch Confirmed to the Supreme Court, CNN (Apr. 7, 2017), http://www.cnn.com/2017/04/07/politics/neil-gorsuch-senate-vote/index.ht $\mathrm{ml}$ [https://perma.cc/MLG6-LR9N].

${ }^{4}$ See generally Nora Kelly, Why Wasn't Antonin Scalia Given an Autopsy?, THE ATLANTIC (Feb. 17, 2016), https://www.theatlantic.com/politics/archive/2016/02/antoninscalia-autopsy/463251/ [https://perma.cc/PG8U-AQKV] (stating that, while one might assume that a federal investigation would take place, in actuality the local government in a small Texas town handled Justice Scalia's death).

${ }^{5}$ See Antonin Scalia Suffered from Many Health Problems, Doctor Says, CBS News (Feb. 23, 2016), https://www.cbsnews.com/news/antonin-scalia-suffered-from-manyhealth-problems-doctor-says [https://perma.cc/N6GG-9GCU].

${ }^{6}$ See Kelly, supra note 4 (noting that local justices of the peace were initially called to examine Justice Scalia's death, but they were not available; a county judge pronounced Scalia dead of natural causes over the phone); see also Mark Berman, Texas Judge Defends Decision Not to Order Autopsy for Justice Scalia, WASH. Post (Feb. 16, 2016), https://www.washingtonpost.com/news/post-nation/wp/2016/02/16/texas-judge-defendsdecision-not-to-order-autopsy-for-justice-scalia [https://perma.cc/78E8-4LGP] (reporting that the county judge who pronounced Justice Scalia dead of natural causes without an autopsy did so out of respect for Justice Scalia's family's wishes).

${ }_{7}^{7}$ See Kelly, supra note 4 (noting that, under Texas law, an over-the-phone death investigation is legal). 
investigator examines the deceased, investigates the scene, and makes a determination concerning the extent to which further investigation is needed. ${ }^{8}$ Despite these lofty responsibilities, each state sets its own standards on what type of death investigation system to utilize and what qualifications are necessary for becoming a death investigator. ${ }^{9}$ Regardless of the system selected, death investigators are intended to serve as an independent body that answers important personal and social questions about the cause and nature of deaths. ${ }^{10}$ To meet these goals, they provide evidence to prosecution and defense teams in criminal and civil cases. ${ }^{11}$

The actuality, however, has fallen far short of the ideal. While death investigators may generally be successful at classifying deaths, limited resources, bureaucratic realities, and the types of work they do have placed them in close proximity with prosecutors, ultimately jeopardizing their objectivity and their independence. ${ }^{12}$ The system is structured in a way that places defense teams at a disadvantage and creates a situation that is ripe for conflicts of interest between death investigators and prosecutors. ${ }^{13}$ Some of these conflicts might result from outright collusion, while others may present themselves in subtle ways. ${ }^{14}$ Even the most well-intentioned death investigators might find themselves in situations in which they are influenced by the pressures of the system. ${ }^{15}$

This Article explores the relationship between death investigators and prosecutors, and how the structure of the system leads to conflicts of interest between them. Part I explores the essential actors who operate in the death investigation system and how the system is constrained by prosecutorial discretion and official immunity. Part II examines how conflicts of interest manifest between death investigators and prosecutors, specifically due to both

${ }^{8}$ FAQ, Am. BD. Medicolegal DeAth InVESTigators, http://www.abmdi.org/faq [https://perma.cc/VWR7-WBD7].

${ }^{9}$ See Things to Know-No National Standards, Little Oversight, PBS (Feb. 1, 2011), [hereinafter Things to Know] http://www.pbs.org/wgbh/pages/frontline/postmortem/things-to-know/no-standards.html [https://perma.cc/WLW2-MX22] (explaining that there is no federal oversight of death investigations and very few offices are accredited, resulting in variations among states).

${ }^{10} \mathrm{See}$ Inst. OF Med., Bd. of Health Promotion \& Disease Prevention, Medicolegal Death InVEstigation System: Workshop Summary 7, 32-33 (2003) [hereinafter Medicolegal Death InVestigation System] ("To ensure the quality and integrity of death investigations, medical ... professionals should form institutions that are truly independent.").

${ }^{11}$ See id. at 7.

${ }^{12}$ See id. at 10-11, 33 (discussing the challenges facing the death investigation field and the proximity of prosecutors to death investigators).

${ }^{13}$ See id. at 31 (stating that the defense has the right to participate in the medical investigation, but it is nearly impossible because the defendant can rarely find a death investigator in the twenty-four-hour limit).

${ }^{14}$ See id. at 31-32.

${ }^{15}$ See id. (highlighting instructions from prosecutors to medical examiners to testify in a way that does not allow cross-examination from a defense attorney). 
inappropriate influence and the proximity of the death investigator and prosecutor offices. Part III highlights the most crucial recommendations for strengthening and reforming the death investigation system: establishing a federal agency to implement uniform death investigation standards; abolishing the coroner system in favor of a medical examiner system; and requiring advanced medical training and education for future death investigators. The Article concludes that implementing these recommendations will help correct the focus of the death investigation system towards a more balanced and independent organization.

\section{BACKGROUND}

When a person dies of unexplained or suspicious causes, the American death investigation system begins to examine the circumstances surrounding the death. ${ }^{16}$ Generally, the system is composed of medical and forensic experts who investigate the scene of death and examine the corpse via an autopsy. ${ }^{17}$ Death investigators provide critical forensic evidence and testimony, which helps parties - such as the prosecution - develop a theory explaining the cause of death. ${ }^{18}$ In circumstances in which foul play is suspected, investigators provide evidence and reports to the prosecutor. ${ }^{19}$ The prosecutor is endowed with great discretionary powers that shape how investigations proceed. ${ }^{20}$ While potentially constrained by some standards that protect defendants, the prosecutor influences the death investigation system by dictating the ways in which results may be used, potentially influencing the actions of the investigators. $^{21}$ This Part explores the history and structure of the death investigation system and explains how prosecutorial discretion, evidentiary standards, and immunity constrain death investigators.

\section{A. Death Investigators}

Death investigations classify the circumstances surrounding a suspicious or unexplained death. ${ }^{22}$ Death investigators inspect crime scenes, perform

16 Medicolegal DeAth InVESTigation System, supra note 10 , at 7.

17 See id. at $7-8$.

18 See id. at 31-32.

${ }^{19}$ See id. at 31 . The death investigator goes to the scene of the death, examines the body and the surrounding area, takes photographs of the scene, transports the body to their office, and generally usually performs an autopsy. $I d$. The evidence collected through this process is passed on to the prosecutor. $I d$.

${ }^{20}$ See id.

21 See infra Parts II.B.2-3.

${ }^{22}$ Suspicious or unexplained deaths that require a death investigation typically include "homicides, suicides, unintentional injuries, drug-related deaths, and other deaths that are sudden or unexpected. Approximately $20 \%$ of the 2.4 million deaths in the US each year are investigated by medical examiners and coroners ...." MEDICOLEGAL DEATH INVESTIGATION SYSTEM, supra note 10, at 7. 
autopsies, and classify deaths resulting from crimes, health, safety or environmental hazards, and inadequate medical care. ${ }^{23}$ There is no centralized federal investigation system. ${ }^{24}$ States thus have flexibility to choose among a coroner system, a medical examiner system, or a hybrid system. While states choose which system will work best based on their needs and available resources, the lack of a uniform system has led to many inconsistencies across the country. ${ }^{25}$ This Section considers how the death investigation system changed over time and how these systems continue to operate today.

\section{History and Advances}

The earliest death investigations were conducted by coroners who, during twelfth century England, determined whether property of the deceased would go to the king. ${ }^{26}$ Coroners, or "crowners," as they were originally known, protected the king's proprietary interest against various individuals and groups who attempted to take possession of real and personal property that became available after suspicious deaths. ${ }^{27}$ It was not until 1887 that coroners shifted their focus from protecting the king's interests to making medical determinations regarding the cause of death. ${ }^{28}$ Additionally, coroners were appointed based on political favoritism, thus leading to a potentially corrupt system. ${ }^{29}$

The coroner system came to America with the earliest settlers, as signified by the first inquest in $1635 .{ }^{30}$ At first, the American system mirrored the English system in that coroners were appointed; over time, however, America began to elect coroners. ${ }^{31}$ The move from appointments to elections was aimed at reducing corruption within the coroner system and preventing coroners from

${ }^{23}$ See id. Modern-day death investigations are divided into three categories: medicolegal, institution-based, and private investigation. RANDY HANZLICK, DEATH INVESTIGATION: Systems AND PROCEDURES 11-12 (2007). This Article focuses on medicolegal investigations.

24 See Things to Know, supra note 9.

25 See Medicolegal Death InVestigation System, supra note 10, at 9.

${ }^{26}$ See id. at 8; Cyril H. Wecht, Legal Medicine and Forensic Science: Parameters of Utilization in Criminal Cases, 34 DuQ. L. REV. 797, 799-800 (1996).

${ }^{27}$ Wecht, supra note 26, at 799-800. "If a carriage with six horses had been involved in the negligent death of someone, if a ship had gone aground on the shoals and killed some people and there was a cargo, these instruments of death might be confiscated and taken by the king." Id. at 799 .

${ }^{28}$ Id. at 801; History, CORONERS' SOC'Y ENG. \& WALES, https://www.coronersociety. org.uk/the-coroners-society/history/ [https://perma.cc/C44S-W5JE].

${ }^{29}$ See Wecht, supra note 26, at 799.

30 Jennifer Moore, Coroners' Recommendations and the Promise of SAVEd LIVES 39 (2016) (describing the English coroner system and how it was transposed to the colonies several centuries later); see also Wecht, supra note 26, at 799-800 (same).

${ }^{31}$ MOORE, supra note 30, at 40. 
using their power for self-serving interests. ${ }^{32}$ These changes did little to improve the quality of the death investigation system, however; political issues and scandals ${ }^{33}$ continued to be a problem. ${ }^{34}$ Catalyzed by consistent coroner inadequacies and scientific advances, many states began to move away from the traditional coroner system by adopting or supplementing their systems with a medical examiner. ${ }^{35}$ This shift to a medical examiner paradigm was aimed at improving the quality of death investigations by requiring medical examiners to meet certain qualifications, such as holding an advanced medical degree. ${ }^{36}$ In addition, through model rules and ethical standards, states have attempted to unify their death investigation systems across jurisdictions. ${ }^{37}$ Despite these various reform attempts, however, the death investigation system in America remains disjointed at the state and county levels. ${ }^{38}$

${ }^{32}$ See id. at 39 (noting that the credibility of coroners was reduced over time because the office was over-politicized and filled with unqualified individuals).

${ }^{33}$ See, e.g., Wecht, supra note 26 , at $801-02$.

${ }^{34}$ MOORE, supra note 30 , at 39 (illustrating how corruption in the coroner system galvanized the reform movement).

35 See HANZLICK, supra note 23, at 42. For example, in 1877, Massachusetts abolished the coroner system in favor of a medical examiner system, which required death investigators to have medical experience. Paul MacMahon, The Inquest and the Virtues of Soft Adjudication, 33 YAlE L. \& POL'Y REV. 275, 282 (2015); see also Robert D. Felder, Comment, A Coroner System in Crisis: The Scandals and Struggles Plaguing Louisiana Death Investigation, 69 LA. L. REV. 627, 633 (2009) (stating that the first major reforms to the coroner system in the U.S. occurred due to several scandals).

36 See Medicolegal Death InVestigation System, supra note 10, at 23-24 (describing the benefits of instituting a medical examiner system over a coroner system, including improved quality of death investigations, uniformity, and central administration).

${ }^{37}$ In 1928, the National Academy of Sciences first addressed the state of death investigation, making specific recommendations: "(1) that the office of coroner be abolished ... (2) that the medical duties of the coroner's office be vested in the office of medical examiner; (3) that the office of medical examiner be headed by a scientifically trained and competent pathologist." NAT'L RESEARCH COUNCIL OF THE NAT'L ACADEMIES, Strengthening Forensic ScIENCE IN THE United States: A PATH ForWARD 242 (2009) [hereinafter A PATH FoRWARD]; see also Andrea R. Tischler, Speaking for the Dead: A Call for Nationwide Coroner Reform, 33 Sw. U. L. REV. 553, 556 (2004).

38 Tischler, supra note 37 , at 557.

The first thing one must realize is that the word "system" is a misnomer, when used in the context of death investigation in the United States. There is no "system" of death investigation that covers the more than 3,000 jurisdictions in this country. No nationally accepted guidelines or standards of practice exist for individuals responsible for performing death-scene investigations. No professional degree, license, certification, or minimum educational requirements exist, nor is there a commonly accepted training curriculum. Not even a common job title exists for the thousands of people who routinely perform death investigations in this country.

Dep't of Justice, Death Investigation: A Guide for the Scene Investigator 1 (1999). 


\section{Modern Day Death Investigation Systems}

Today, death investigation systems exist primarily as coroner systems or medical examiner systems, with some variations. Coroners and medical examiners direct teams of experts that include professionals such as forensic pathologists, forensic scientists, toxicologists, and scene investigators. ${ }^{39}$ While qualifications for coroners and medical examiners vary from state to state, the death investigator's role remains constant: to examine suspicious and unexplained deaths. There are four basic death investigation systems in the United States: (1) a county-, district-, or parish-based coroner system; ${ }^{40}$ (2) a centralized medical examiner system; (3) a county- or district-based medical examiner system; and (4) a hybrid/mixed system. ${ }^{41}$ When deciding which type of system to implement, jurisdictions weigh several factors, such as the availability of existing and future funding, a state's population density, qualified personnel, and a locality's organizational structure. ${ }^{42}$

\section{a. Coroner System}

While there have been advances in medical technology, the framework and purpose of the coroner system have remained relatively constant since it came to America. Coroners today are still empowered to, among other things, certify the cause and manner of unexplained or unnatural deaths. ${ }^{43}$ In all

${ }^{39}$ See HANZLICK, supra note 23, at 49 (listing the major disciplines of forensic sciences); What Is a Coroner?, CRIMESCENEINVESTIGATOREDU, https://www.crimescene investigatoredu.org/coroner [https://perma.cc/M5BW-9NBZ].

${ }^{40}$ For this category, the CDC includes any state in which all counties, districts, and parishes are served by a coroner, even if there is an overall state medical examiner's office. Death Investigation Systems, CTRS. FOR DiseASE CONTROL \& PREVENTION (last updated Oct. 26, 2016), http://www.cdc.gov/phlp/publications/coroner/death.html [https://perma.cc/ Z9AD-UMR2]. Some scholars categorize these types of states as hybrid/mixed. See HANZLICK, supra note 23, at 89-97.

${ }^{41}$ Death Investigation Systems, supra note 40. A hybrid/mixed system generally means that the state has some coroners, but also has at least one county with a medical examiner system. See HANZLICK, supra note 23, at 89.

42 See A PATH FORWARD, supra note 37, at 257 (noting that many death investigator positions remain vacant "because of manpower shortages and/or insufficient funding of pathologist positions"). In Georgia, the mayor may perform coroner duties in municipalities with 5,000 people or fewer. GA. CODE ANN. § 45-16-1 (2016). In Washington, in counties with fewer than 40,000 people, the local prosecutor is the exofficio coroner. WASH. REV. CODE ANN. § 36.16.030 (West 2003 \& Supp. 2018). In Wisconsin, cities with fewer than 500,000 residents are not allowed to have a coroner and those with more than 500,000 have the option to have a coroner; two or more counties may also institute a joint medical examiner system in Wisconsin. WIS. STAT. ANN. §59.20 (West 2013 \& Supp. 2015).

${ }^{43}$ There are currently fourteen states that have a county- district- or parish-based coroner system. ARK. CODE ANN. § 14-15-301 (2013); Colo. ReV. STAT. § 30-10-601 (2017); IDAHO CODE § 34-622 (Michie 2015); IND. CODE ANN. § 36-2-14-2 (West 2006); 
coroner jurisdictions, the position of coroner is elected and must meet only the most basic qualifications; generally, there are no age, education, or even medical training requirements. ${ }^{44}$ Indiana, for example, requires only that the county coroner reside in the state, attend a forty-hour training course within six months of taking office, and take an eight-hour training course each year. ${ }^{45}$ Some states allow government officials-such as the sheriff, justice of the peace, or prosecutor - to assume coroner duties in lieu of having a separate office of the coroner. ${ }^{46}$

\section{b. Medical Examiner System}

Unlike the coroner system, which requires few qualifications, the medical examiner system adheres to strict education and medical training requirements. A medical examiner is a forensic doctor who uses his or her medical expertise when conducting death investigations, including performing autopsies. ${ }^{47}$ Moreover, medical examiners are civil servants as opposed to elected officials. Because medical examiners have greater medical expertise than most coroners, many states have abandoned their coroner system entirely or supplemented that system with medical examiners. ${ }^{48}$

Kan. Stat. AnN. § 22a-226 (West 2008); Ky. ReV. STAt. AnN. § 72.410 (LexisNexis 2014); La. STAt. ANN. § 13:5701 (2012); Mont. Code ANN. § 7-4-2901 (2015); NeB. ReV. STAT. ANN. § 23-1820 (LexisNexis 2011); NEV. REV. Stat. AnN. § 259.010 (LexisNexis 2011); N.D. CENT. CODE § 11-10-02 (2012); S.C. CODE ANN. § 17-5-5 (2014); S.D. CODIFIED LAWS § 7-7-1.1 (2004); Wyo. STAT. ANN. § 7-4-101 (2017).

${ }^{44}$ But see KAN. STAT. ANN. § 22a-226 (2017) (requiring all coroners to be licensed physicians).

${ }^{45}$ IND. CodE ANN. §§ 36-2-14-2, -22.3, -23 (West 2006 \& Supp. 2015).

46 See, e.g., NeB. ReV. Stat. AnN. § 23-1210 (LexisNexis 2011) ("The county attorney shall perform all of the duties enjoined by law upon the county coroner and the county attorney shall be the ex officio county coroner."); Death Investigation Systems, supra note 40 (finding that Hawaii's chief of police is authorized to play a significant role in a death investigation, and that justices of the peace in Texas can perform coroner duties). This feature can also apply to coroners in a hybrid or mixed system. See, e.g., HAw. REV. STAT. ANN. \$841-1 (West 2008) ("The chief of police or his authorized subordinate ... shall, ex officio, be the coroner for his respective county.").

${ }^{47}$ See What Is a Coroner?, supra note 39 (explaining that coroners may be medical professionals and may perform autopsies). But see W. VA. CODE § 61-12-7 (2016) (explaining that, in West Virginia, the office of medical examiner may be held by nonphysicians, such as nurses, paramedics, or physicians' assistants).

${ }^{48}$ Sixteen states and the District of Columbia have centralized medical examiner systems. Alaska Stat. § 12.65.015 (2016); Conn. Gen. Stat. AnN. § 19a-406 (West 2011); Del. Code AnN. tit. 29, § 4704 (Michie 2017); D.C. Code § 5-1402 (2001 \& Supp. 2018); Me. Rev. Stat. AnN. tit. 22, § 3023 (2004 \& Supp. 2017); Md. Code AnN., HEALTH-GEN. § 5-306 (LexisNexis 2015); MASS. ANN. LAWS ch. 38, § 2 (LexisNexis 2006 \& Supp. 2016); N.H. ReV. STAT. ANN. § 611-B:2 (2001 \& Supp. 2017); N.M. STAT. ANN. $\S$ 24-11-3 (LexisNexis 2015); N.C. Gen. StAT. § 130A-382 (2015); OKLA. STAT. ANN. tit. 63, § 937 (West 2016); OR. REv. STAT. § 146.065 (2017); 23 R.I. GEN. LAWS § 23-4-2 (2008); Utah Code ANN. § 26-4-4 (LexisNexis 2013 \& Supp. 2016); Vt. STAT. AnN. tit. 
Unlike the general standards for coroners, most jurisdictions require, at a minimum, that medical examiners "be physicians licensed to practice medicine...."49 Other jurisdictions, like New Hampshire, impose more significant educational standards, requiring that medical examiners be certified pathologists. ${ }^{50}$ In Massachusetts, the chief medical examiner must be a physician licensed to practice in the Commonwealth and a graduate of an approved fellowship program in forensic medicine with a certification in anatomic pathology and subspecialty certification in forensic pathology. ${ }^{51}$ New Jersey, while similar to New Hampshire and Massachusetts, imposes additional training, requiring thirty hours of basic education in death investigation, sponsored by an institution of higher education or other agency approved by the State Medical Examiner; a basic course conducted by the Office of the State Medical Examiner; and seven full days of internship training at the New Jersey State Medical Examiner Office. ${ }^{52}$

While a medical examiner system is more reliable than the coroner system, the diverse requirements from one jurisdiction to another prevent uniform training across the country, leading to barriers to entry in a field that is greatly in need of qualified professionals. Although many jurisdictions may prefer to rely on medical examiners rather than coroners, there are not enough qualified medical examiners in the United States to staff all of the open positions. ${ }^{53}$ The strict requirements of the medical examiner system led to more comprehensive death investigations, but those requirements also prevent many offices from staffing all available positions. ${ }^{54}$

18, §507 (2017); VA. Code ANN. §32.1-277 (2015); W. VA. Code ANN. §61-12-7 (LexisNexis 2014). Six states have county- or district-based medical examiner systems. ARIZ. ReV. StAT. ANN. § 11-592 (2012); Fla. StAT. ANN. § 406.05 (West 2016); IowA ADMIN. CODE r. 641-127.1 (2018); Mich. COMP. LAWS SERV. $\$ 52.201$ (LexisNexis 2006); N.J. Stat. ANN. § 52:17B-83 (West 2010); TenN. CodE ANN. § 8-9-101 (2016); see also Death Investigation Systems, supra note 40 (noting that Tennessee allows for counties to maintain a coroner system, but there are currently no active coroners).

${ }^{49}$ See D.C. CODE § 5-1402; see also ME. REV. StAT. ANN. tit. 22, § 3022 ("The Chief Medical Examiner must possess a degree of doctor of medicine or doctor of osteopathy, be licensed to practice in the State and be expert in the specialty of forensic pathology.").

${ }^{50}$ N.H. REV. STAT. ANN. § 611-B:2.

${ }^{51}$ MASS. ANN. LAWS ch. $38, \S 2$.

52 N.J. ADMIN. CODE 13:49-7.1 (2018).

53 A PATH FORWARD, supra note 37, at 257-58 (explaining that, at this time, the estimated need is for about 1,000 forensic pathologists; about $10 \%$ of available positions are vacant because of manpower shortages). While seventy forensic pathology positions become available each year, only $70 \%$ of those available positions are ultimately filled. $I d$. at 257. Many of these positions remain vacant due to lack of funding and manpower shortages. Id.

${ }^{54}$ See HANZLICK, supra note 23, at 42 (noting that the lack of qualified professionals and unfilled positions leads to varying quality in death investigations). 


\section{c. Hybrid Systems}

Dispersed populations, a dearth of qualified medical examiners, and inconsistent political will have led some states to employ a hybrid death investigation system - one in which counties across a state vary in terms of whether they use a coroner or medical examiner. ${ }^{55}$ Alabama provides an interesting example of this approach. It is statutorily classified as a coroner system, ${ }^{56}$ but in practice it qualifies as a hybrid system because at least three counties abolished the office of the coroner and replaced it with the office of a medical examiner. ${ }^{57}$ The hybrid systems encapsulate the overall deficiencies and lack of uniformity of the death investigation system. ${ }^{58}$ The patchwork of laws and approaches employed across states causes confusion for those trying to understand death investigations in America. ${ }^{59}$

\section{B. Prosecutors}

The structure of the death investigation system gives prosecutors enormous control over scientific evidence and testimony, which in turn helps to further their case theories. This arrangement, coupled with a prosecutor's largely unfettered discretion, creates great potential for abuse. Prosecutorial discretion dictates the direction, outcome, and underlying mechanisms of criminal cases. ${ }^{60}$ Indeed, one federal district judge recently wrote that, "for the immediate future at least, prosecutors, rather than judges, will be the real rulers of the American criminal justice system. And I ask you: is that fair?"61

Current constraints meant to lessen abuse of prosecutorial discretion fall short of eliminating conflicts of interest and reducing prosecutorial control.

55 Fifteen states currently have a hybrid/mixed system. ALA. CODE § 11-5-1 (LexisNexis 2008); ALA. CODE $§ 45-27-60$ (2011); CAL. GOV’T CODE $§ 24010$ (West 2003); CONN. Gen. Stat. AnN. § 19a-406 (West 2011); GA. CODE ANN. § 45-16-80 (2016); HaW. Rev. Stat. AnN. § 841-1 (West 2008); 55 Ill. Comp. Stat. AnN. 5/3-3003, -3044 (West 2004); MinN. Stat. ANN. § 390.005 (West 2005 \& Supp. 2016); Miss. CodE ANN. § 41-6157 (West 2007 \& Supp. 2017); Mo. ReV. STAT. $\S \S 58.010,58.700$ (West 2017); N.Y. COUNTY LAW $\S 671$ (McKinney 2017); OHIO REV. CODE ANN. § 313.01 (LexisNexis 2016); 53 Pa. Stat. and Cons. Stat. AnN. § 3092 (West 2016); TeX. Code Crim. Proc. AnN. art. 49.02, .04, .25 (West 2006); WASH. Rev. Code ANN. § 36.16 .030 (West 2003 \& Supp. 2018); Wis. STAT. ANN. § 59.20 (West 2013 \& Supp. 2015).

56 ALA. CODE § 11-5-1.

57 See Death Investigation Systems, supra note 40.

58 See Beth Pearsall, Improving Forensic Death Investigation, NAT'L INST. JUST. (Mar. 3, 2011), https://www.nij.gov/journals/267/pages/investigation.aspx [https://perma.cc/5KLW-LZ2E] (discussing the deficient death investigation system and possible solutions).

${ }^{59}$ See id.

60 See Russell L. Weaver et Al., Principles of Criminal Procedure 291 (3d ed. 2008).

61 Jed S. Rakoff, Why Prosecutors Rule the Criminal Justice System-And What Can Be Done About It, 111 Nw. U. L. REV. 1429, 1436 (2017). 
This Section explores the prosecutor's role in death investigations, how their discretion increases their authority, and how existing constraints are ineffective.

\section{The Modern Prosecutor's Role in the Death Investigation}

The modern prosecutor fulfills a dual role of an adversary and an agent of the sovereign. As an adversary, the prosecutor's goal is to win the case; as an agent of the sovereign, the prosecutor must seek both the conviction of the guilty and the acquittal of the innocent. ${ }^{62}$ In these dual roles, prosecutors have significant discretion concerning whether to bring a case, what charges to file, and what sentence to pursue. ${ }^{63}$ During a death investigation, prosecutors work closely with death investigators and law enforcement to determine the cause of death and whether the state should seek charges. ${ }^{64}$ As part of this work, prosecutors have control over scientific evidence, the ability to shape the facts, and the power to persuade a factfinder of a defendant's guilt. A prosecutor's dominion over criminal proceedings constrains the objectivity and independence of the death investigation system, essentially situating death investigators under the direct command of prosecutors.

One may think that, in a death investigation, the prosecutor steps in after all of the evidence has been collected and the facts are set. In reality, however, the prosecutor's influence commences at the beginning of the investigation. ${ }^{65}$ The structure of the criminal justice system is such that death investigators and prosecutors are intended to be independent entities. But they are housed under the same governmental framework, thus placing them ostensibly on the same team. ${ }^{66}$ In some cases, they even work in the same building, further blurring the lines of independence. ${ }^{67}$ This architecture enables prosecutors to influence

${ }^{62}$ See Charlie DeVore, Comment, A Lie Is a Lie: An Argument for Strict Protection Against a Prosecutor's Knowing Use of Perjured Testimony, 101 J. CRIM. L. \& CRIMINOLOGY 667, 667 (2011) (noting that prosecutors must balance the desire to achieve legislative victories with justice and fairness); see also United States v. Agurs, 427 U.S. 97, 110-11 (1976) ("[T]hough the attorney for the sovereign must prosecute the accused with earnestness and vigor, he must always be faithful to his client's overriding interest that justice shall be done. He is the servant of the law, the twofold aim of which is that guilt shall not escape or innocence suffer." (citation and internal quotation marks omitted)).

${ }^{63}$ See WEAVER ET AL., supra note 60, at 291 (stating that prosecutorial discretion is rooted in the separation of powers doctrine and that such discretion is "ill-suited to judicial review" (quoting Wayte v. United States, 470 U.S. 598, 607 (1985)).

${ }^{64}$ See Medicolegal Death InVESTIGATION SYSTEM, supra note 10, at 31 (explaining that after a suspected homicide, prosecutors consult with death investigators to determine the manner, cause, and time of death).

65 See id.

${ }^{66}$ See id. at 33 (lamenting the control that prosecutors have over the death investigators resulting from the institutional framework).

${ }^{67}$ See id. at 36-37 (arguing that death investigator offices should be removed from departments of public safety like prosecutor and police offices in order to reduce conflicts of interest). 
scientific evidence and testimony, sometimes creating substantial conflicts of interest.

\section{Prosecutorial Discretion}

Prosecutorial discretion is a key component of the criminal justice system. Without this discretion, prosecutors' limited time and resources might be spent on frivolous or unwarranted cases. ${ }^{68}$ Discretion allows prosecutors to prioritize cases according to the social and political priorities of the jurisdiction. ${ }^{69}$ In a practical sense, discretion may lead to more just outcomes because it allows prosecutors to balance real life circumstances with black letter law. ${ }^{70}$

Despite the need for prosecutorial discretion, the seemingly unlimited ability of the prosecutor to control a case often results in the abuse of power. ${ }^{71}$ Furthermore, there is no substantive check on a prosecutor's discretion; they are accountable only to a supervisor who usually has the same goals and interests, and public mechanisms generally are ineffective at holding prosecutors accountable. ${ }^{72}$ With a culture of winning at all costs and pursuing convictions with zeal, prosecutors - knowingly or unknowingly - may cross the line into questionable or illegal behavior, creating conflicts of interest. ${ }^{73}$ Without meaningful standards or reform, prosecutorial misconduct and questionable practices are rarely challenged. ${ }^{74}$

68 Angela J. DAVis, Arbitrary Justice: The Power of the AMERICAN PRoseCUTOR 13 (2007). Nationwide, local criminal justice systems do not have enough resources to pursue charges in every alleged criminal case. Id. at 13-14; see also RONALD J. Allen et Al., Criminal Procedure: InVESTigation AND Right to Counsel 4 ( $3 \mathrm{~d}$ ed. 2016) (explaining that the availability of resources may force prosecutors to be selective in choosing cases to prosecute).

${ }^{69}$ See DAVid K. ShiPler, Rights at Risk: The Limits of Liberty in MODERN AMERICA 108 (2012).

70 See Ronald Wright \& Marc Miller, The Screening/Bargaining Tradeoff, 55 Stan. L. REV. 29, 30-35 (2002) (arguing that appropriate use of prosecutorial discretion, or "screening," may result in only "appropriate charges" being filed, which can lead to a more balanced and fair system).

${ }^{71}$ See Angela J. Davis, The American Prosecutor: Independence, Power, and the Threat of Tyranny, 86 IowA L. REV. 393, 397, 399 (2001).

72 Id. at 397 ("Most citizens know very little about the practices and policies of their local prosecutor."); DAVIS, supra note 68, at 16.

${ }^{73}$ DAVIS, supra note 68, at 16-18. "[E]ven well-meaning prosecutors often fail because they exercise discretion arbitrarily and without guidance and standards, under the daily pressures of overwhelming caseloads in a system with inadequate representation for most defendants, and judges who are more interested in efficiency than justice." Id. at 16.

${ }^{74}$ Daniel Woislaw, Comment, Absolute Immunity: Applying New Standards for Prosecutorial Accountability, 26 GEO. MASON U. C.R.L.J. 349, 365-66 (providing data reflecting the lack of professional and criminal liability and professional disciplinary action for prosecutors who have engaged in prosecutorial misconduct leading to wrongful convictions). But see Tony Saavedra, Prosecutors Who Falsify or Withhold Evidence 


\section{Constraints on Prosecutors}

Despite the prosecutor's apparently unlimited authority, there are numerous constraints on prosecutorial discretion, from a defendant's right against self-incrimination to due process protections. Most prevalent to the death investigation system are standards that constrain prosecutors in their use of scientific evidence and testimony. The standard set out in Brady $v$. Maryland ${ }^{75}$ is a prime example of how evidentiary standards that require strict disclosure may curb abuses of prosecutorial discretion. ${ }^{76}$ Brady imposes an affirmative obligation on prosecutors to disclose exculpatory evidence to the defendant and applies, for example, when prosecutors solicit false testimony or allow false testimony to go uncorrected. $^{77}$ If a prosecutor fails in this obligation, provided the issue at hand is material, the defendant is typically entitled to a new trial. ${ }^{78}$

In theory, standards such as Brady place a check on prosecutorial discretion; in reality, however, these standards fall short of protecting the innocent and fail to sufficiently condemn prosecutorial abuse. ${ }^{79}$ When examining an alleged Brady violation, courts require a finding of egregious misconduct and require defendants to meet a nearly unattainable bar of materiality. ${ }^{80}$ Such insubstantial constraints mean that prosecutors are rarely

Could Become Felons Under Proposed State Legislation, ORAnge CounTy REg. (Aug. 11, 2016), http://www.ocregister.com/articles/county-725339-prosecutors-orange.html [https://perma.cc/9D2D-JUBA] (describing proposed penalties of between sixteen months and three years for prosecutors who intentionally falsify or withhold evidence).

75373 U.S. 83 (1963).

${ }^{76}$ In addition to the Brady standard, the Napue standard guides prosecutors in their use of evidence and testimony. The Napue standard declares that a prosecutor's knowing misuse of false evidence or testimony at trial is a violation of due process. See Napue v. Illinois, 360 U.S. 264, 269 (1959) (holding that the Fourteenth Amendment Due Process Clause bars prosecutors from knowingly presenting false testimony and obligates them to correct such testimony when it occurs).

${ }^{77}$ See Brady, 373 U.S. at 87 ("We now hold that the suppression by the prosecution of evidence favorable to an accused upon request violates due process where the evidence is material either to guilt or to punishment, irrespective of the good faith or bad faith of the prosecution."); see also BenNETT L. GERSHMAn, PROSECUTORIAL Misconduct 243 (2d ed. 2015) ("Nondisclosure of exculpatory evidence by prosecutors is one of the most pervasive forms of prosecutorial misconduct, and may account for more miscarriages of justice than any other type of prosecutorial infraction.”).

78 See Giglio v. United States, 405 U.S. 150, 153 (1972) (explaining that Brady holds that suppression of material evidence by a prosecutor, regardless of good or bad faith, "justifies a new trial").

${ }^{79}$ See Cynthia E. Jones, A Reason to Doubt: The Suppression of Evidence and the Inference of Innocence, 100 J. CRIM. L. \& CRIMINOLOGY 415, 434 (2010) ("[T]he Brady disclosure duty has become one of the most unenforced constitutional mandates in the criminal justice system.”).

${ }^{80}$ See, e.g., Giglio, 405 U.S. at 154 (indicating that a Brady violation results in a new trial when the violation materially affects the outcome of a case); United States v. Reese, 745 F.3d 1075, 1083 (10th Cir. 2015) ("Evidence is material if there is a reasonable 
investigated or disciplined, even when a defendant's rights have clearly been violated. ${ }^{81}$ Since the standard is so high, most allegations fail to trigger a Brady violation. Even well-meaning prosecutors, through their relationship and access to death investigators, can bend the results of an investigation and encourage the production of false or misleading evidence that may send an innocent defendant to prison.

In addition to the difficulties associated with asserting a Brady violation, statutory immunity serves to insulate prosecutors from misconduct charges. Even when government officials act illegally or unethically, they generally enjoy immunity as long as they are "acting within the scope of their employment," regardless of the nature of the violation. ${ }^{82}$ The provision of immunity is an attempt to balance both the need to hold officials accountable and the need to protect officials acting reasonably from "harassment, distraction, and liability." 83 But just as disclosure obligations are ineffective at holding prosecutors accountable, immunity shields prosecutors from misconduct claims and lowers the bar of accountability. ${ }^{84}$

The opportunity for the misuse of scientific evidence and testimony, coupled with an unattainable immunity standard, complicates how prosecutors interact with death investigators. The system is already structured in a way that lends itself to conflicting interests for prosecutors and death investigators. Without proper checks on that system, however, conflicts may go unchecked or unresolved. On one level, the evidentiary standards established by courts seem to indicate a willingness to address these problems. On another level, though, the inability of the public to hold officials accountable cuts the other way. The following Part highlights the improper association between prosecutors and death investigators resulting from the failure of the constraints on both offices.

probability that the result of the proceeding would have been different had the evidence been disclosed. A reasonable probability means the likelihood of a different result is great enough to undermine confidence in the outcome." (citation and internal quotation marks omitted)).

${ }^{81}$ Cadene A. Russell, Comment, When Justice Is Done: Expanding a Defendant's Right to the Disclosure of Exculpatory Evidence on the 51st Anniversary of Brady v. Maryland, 58 How. L.J. 237, 246-50 (2014) (discussing the shortcomings of Brady in addressing prosecutorial misconduct and noting that the tendency to favor the government "is evident where bar associations are not inclined to 'discipline prosecutors for even the most egregious Brady violations"” (quoting Elizabeth Napier Dewar, A Fair Trial Remedy for Brady Violations, 115 YALE L.J. 1450, 1456 (2006))).

82 See Chesher v. Neyer, 477 F.3d 784, 796 (6th Cir. 2007) (citing OHIO REv. CoDE ANN. § 2744.03(A)(6)).

83 Pearson v. Callahan, 555 U.S. 223, 231 (2009).

${ }^{84}$ See Russell, supra note 81 , at 267 ("Unfortunately, prosecutorial immunity is more of a hindrance to effective Brady policies than it is a benefit."); Woislaw, supra note 74, at 349 (arguing that absolute immunity prevents the public from holding prosecutors accountable for misconduct because it exempts prosecutors from civil liability for violations of individual rights). 


\section{CONFLICTS OF INTEREST}

The term "conflict of interest" elicits visions of outright corruption and backroom deals. While conflicts of interest may be apparent in some circumstances, they can also result from discreet pressures over time. ${ }^{85}$ It is difficult to define or understand what constitutes a conflict of interest, ${ }^{86}$ in part because many professionals do not believe they could possibly fall victim to inappropriate influences; as a result, they often overlook the subtle tensions in their professional lives. ${ }^{87} \mathrm{~A}$ conflict of interest occurs between a death investigator and a prosecutor when one party submits to competing interests or loyalties, ${ }^{88}$ whether knowingly or unknowingly, and it adversely affects an individual's independent and professional judgment. 89

Prosecutors and death investigators confront personal and institutional pressures resulting in pervasive conflicts of interest that undermine their independence and integrity. While the two offices have distinct goals, ${ }^{90}$ the prosecutor's commanding authority over medical evidence, combined with a close relationship with the death investigator's office or the individual death investigator on the case, gives the prosecutor overwhelming influence in the relationship. ${ }^{91}$ That influence may push the investigator to knowingly or

${ }^{85}$ Don A. Moore et al., Introduction, in CONFLICTS OF InTEREST: CHALlENGES AND Solutions in Business, Law, Medicine, And Public Policy 3 (Don A. Moore et al. eds., 2005) [hereinafter CONFLICTS OF INTEREST].

${ }^{86}$ Samuel Issacharoff, Legal Responses to Conflicts of Interest, in CONFLICTS OF INTEREST, supra note 85, at 191.

${ }^{87}$ CONFLICTS OF INTEREST, supra note 85 , at 3.

${ }^{88}$ See Conflict of Interest, BLACK's LAW DiCTIONARY (10th ed. 2014) (defining "conflict of interest" as "[a] real or seeming incompatibility between one's private interests and one's public or fiduciary duties").

${ }^{89}$ See People v. Clark, 261 P.3d 243, 343-44 (Cal. 2011) (acknowledging that there can be actual and potential conflicts of interest); State v. White, 114 S.W.3d 469, 476 (Tenn. 2003) (defining conflicts of interest as when a professional cannot exercise judgment free of competing interests and loyalties); BENNETT L. GERSHMAN, PROSECUTION STORIES ch. 7 (2017) (discussing "the problem of divided loyalties" and conflicts of interest in specific situations); BRENT E. TURVEY \& STAN CROWDER, ETHICAL Justice: APPlied Issues fOR CRIMINAL Justice StUdents AND PROFESSIONALS 265 (2013) (explaining that conflicts of interest can include a need to satisfy multiple roles, duties, or obligations).

${ }^{90}$ During a death investigation, death investigators analyze scientific evidence to determine the causes and surrounding circumstances of a death; in appropriate cases, prosecutors then actively pursue a conviction. See HANZLICK, supra note 23, at 11 (discussing the role of death investigators within medicolegal death investigations); Carolyn B. Ramsey, The Discretionary Power of "Public" Prosecutors in Historical Perspective, 39 AM. CRIM. L. REV. 1309, 1311-12 (2002) (discussing the historical patterns of prosecutors actively seeking convictions).

${ }^{91}$ See Davis, supra note 71, at 408 (explaining the far-reaching discretion and power of prosecutors in criminal case outcomes); Bennett L. Gershman, Misuse of Scientific Evidence by Prosecutors, 28 OKLA. CITY U. L. REV. 17, 18 (2003) ("[T]he prosecutor 
unknowingly compromise his or her professional independence in many stages of the investigation. These pressures result in overt conflicts of interest, such as collusion between the two offices, ${ }^{92}$ or unconscious and inappropriate influence that threatens the integrity of the entire justice system. ${ }^{93}$

Although conflicts of interest between prosecutors and death investigators pervade the justice system, there has been very little focus on the conflicts between the offices. Instead, scholars have focused on death investigator and prosecutor misconduct separately. ${ }^{94}$ This Section analyzes the interaction between the two offices and what occurs when they are allowed to influence each other without adequate oversight or consequences.

\section{A. Overt and Apparent Conflicts of Interest}

From fraudulent medical exams to state cover-ups, there are many examples of overt conflicts of interest in the death investigation field. Overt conflicts of interest are clear and apparent instances of inappropriate influence created by institutional structures and personal biases. ${ }^{95}$ These conflicts may be separated into two categories: when a prosecutor serves as a coroner ${ }^{96}$ - an inherent institutional conflict — and when at least one party knowingly acts due to inappropriate influence ${ }^{97}$ - a combination of institutional and personal biases. Institutional structures and personal biases allow each office to influence the other and in turn blur the lines of duty, responsibility, and independence. ${ }^{98}$ Overt conflicts of interest are contrary to all principles of justice and fair process.

dominates the system, has exclusive control of the evidence, and decides by himself how that evidence will be used.").

92 See State v. Beecroft, 813 N.W.2d 814, 847-48 (Minn. 2012) (exemplifying how prosecutors may substantially interfere with and pressure death investigators).

${ }^{93}$ See McCarty v. State, 765 P.2d 1215, 1217-18 (Okla. Crim. App. 1988) (describing a case in which a death investigator succumbed to implicit pressures).

${ }^{94}$ See generally Davis, supra note 71, at 408 (examining the effects of prosecutorial discretion); Felder, supra note 35, at 628-30 (providing an example of death investigators who abuse their power); Brandon L. Garrett \& Peter J. Neufeld, Invalid Forensic Science Testimony and Wrongful Convictions, 95 VA. L. REV. 1, 4-12 (2009) (highlighting prosecutor's misuse of erroneous death investigator testimony); Gershman, supra note 91, at 17 (discussing the prosecutor's misuse of scientific evidence while pursuing criminal convictions).

95 See, e.g., Rivas v. Fischer, 687 F.3d 514, 528 (2d Cir. 2012) (illustrating the structure that allows for overt conflicts to occur).

96 See infra Part II.A.1.

97 See infra Part II.B.2.

${ }^{98}$ See Felder, supra note 35, at 628 ("Whether a mistake leads to the wrongful conviction of the innocent, allows the guilty to go free, or allows an unjust award of damages, the ramifications of an ineptly governed death investigation system are felt throughout the entire justice system."). 


\section{Allowing the Prosecutor to Serve as the Coroner Creates an Overt Conflict of Interest}

A feature unique to the coroner system is that some jurisdictions allow officials who already occupy a governmental position also to hold the position of coroner, thus creating an inherent conflict of interest. Pursuant to state statutes, officials such as sheriffs, ${ }^{99}$ mayors, ${ }^{100}$ prosecutors, ${ }^{101}$ and justices of the peace ${ }^{102}$ are permitted to hold the office of the coroner simultaneously. ${ }^{103}$ While states have enacted these statutes to promote efficiency, combat a lack of medical expertise, and manage limited resources, conflicts of interest are unavoidable. 104 When the office that conducts the post-mortem death investigation is the same office that pursues criminal charges against a suspect, the traditionally independent offices often end up with contradictory goals. ${ }^{105}$

${ }^{99}$ See HAW. Rev. Stat. ANN. $\S 841-1$ (West 2008) (permitting the chief of police to serve as coroner in certain counties).

100 See GA. CODE ANN. § 45-16-1 (2016) (allowing mayors in municipalities with populations less than 5,000 people to serve as coroners).

${ }^{101}$ See NeB. REV. STAT. ANN. § 23-1210 (2011) (mandating that the county attorney perform the duties of the coroner); N.D. CENT. CODE § 11-09-27 (2012) (establishing that the sheriff or county manager can perform the duty of the coroner in rare circumstances); WASH. ReV. Code ANN. § 36.16.030 (West 2003 \& Supp. 2018) (requiring the prosecutor to serve as coroner in counties with populations under 40,000 people).

102 See Tex. Code Crim. Proc. ANN. art. 49.04 (West 2006) (stating that the justice of the peace will perform the duty of the coroner). See generally Judy Melinek, Justice Scalia's Unexamined Death Points to a Problem, CNN (Feb. 20, 2016), http://www.cnn.com/2016/

02/18/opinions/justice-scalia-no-autopsy-melinek/ [https://perma.cc/6W9E-V23U]

(discussing conflicts of interest arising from allowing the justice of the peace to issue Justice Scalia's death certificate without visiting the scene or performing an autopsy).

${ }^{103}$ Funeral directors can also serve simultaneously as coroners, thereby creating a conflict of interest when funeral directors arrive at the scene of a crime to garner business. See HANZLICK, supra note 23, at 19, 37.

${ }^{104}$ See Skamania County Coroner, SKAMANIA COUNTY, http://www.skamaniacounty. org/prosecutor/homepage/coroner/ [https://perma.cc/J24H-9ZN8] (stating that counties with limited resources should combine the office of coroner and county prosecutor).

105 See State v. Beecroft, 813 N.W.2d 814, 834 (Minn. 2012) ("[F]orensic science is not and should not become the sole province of the police and prosecutors. In the search for truth and justice, forensic science must be "equally available to law enforcement officers, prosecutors, and defendants." (quoting A PATH FORWARD, supra note 37, at 17)). For a recent example of an alleged conflict of interest on the part of a sheriff who also served as county coroner, see Julie Small, Autopsy Doctor Resigns, Says Sheriff Overrode Death Findings to Protect Officers, KQED News (Dec. 4, 2017), https://ww2.kqed.org/news/2017/12/04/autopsy-doctors-sheriff-overrode-death-findingsto-protect-law-enforcement/ [https://perma.cc/A84T-TJSA]. According to Dr. Bennet Omalu, San Joaquin County, California's chief forensic pathologist, "The sheriff was using his political office as the coroner to protect police officers whenever someone died while in custody or during arrest.... I had thought that this was initially an anomaly, but now, especially beginning in 2016, it has become routine practice." Id. Dr. Omalu added: "The Sheriff does whatever he feels like doing as the coroner, in total disregard of bioethics, 
Allowing the prosecutor to serve as coroner creates an overt conflict because one cannot completely compartmentalize the goals and obligations of each position. On the one hand, prosecutors face pressure to maintain a high conviction rate, while at the same time attempting to seek justice. ${ }^{106}$ On the other hand, coroners aim to conduct thorough, objective death investigations and provide accurate medical results. ${ }^{107} \mathrm{~A}$ prosecutor who serves as coroner may have difficulty balancing these goals and may be inclined to pursue a theory of death that serves the purposes of the prosecution. As previously discussed, prosecutors have a great deal of discretion in the criminal justice system. ${ }^{108}$ Permitting the prosecutor to act as coroner eliminates a check on prosecutorial discretion and provides the prosecutor with even more control over the process. Affording one person this unbridled, virtually unregulated power compromises the independence of each role and the ability to have an objective, correct determination of death and a potentially unbiased trial. ${ }^{109}$

Nevertheless, state courts in Nebraska and Washington have upheld the validity of this relationship. In 1941, in Sturgeon v. Crosby Mortuary, Inc., ${ }^{110}$ for example, the Nebraska Supreme Court sustained the constitutionality of combining the coroner's office and the prosecutor's office. ${ }^{111}$ The court explained that the prosecutor serving as a coroner "constituted a reasonable exercise of the powers of his office."112 More recently, the Nebraska court reiterated the position expressed in Sturgeon by explicitly stating that there is no danger of a conflict of interest when a prosecutor serves as coroner because the prosecutor's judicial duties are separate and distinct from its coroner duties. ${ }^{113}$ While the Nebraska statute permits the prosecutor to serve as coroner, the Washington State statute requires that the prosecutor serve as coroner in cities with populations less than 40,000 people. ${ }^{114}$ Permitting or

standards of practice of medicine and the generally accepted principles of medicine." Id.; see also Radley Balko, It's Time to Abolish the Coroner, WASH. Post (Dec. 12, 2017), https://www.washingtonpost.com/news/the-watch/wp/2017/12/12/its-time-to-abolish-thecoroner/ [https://perma.cc/EHK6-6Y4Z] (stating, inter alia, "[i]n 41 of [California's] 58 counties, the coroner's duties are automatically assumed by the elected sheriff").

${ }^{106}$ DAVIS, supra note 68, at 141 (considering how prosecutors' offices "foster a culture of winning at any cost").

${ }^{107}$ HANZLICK, supra note 23, at 57.

108 See supra Part I.B.1.

109 The American Bar Association has formulated standards for the use of expert medical testimony; when a prosecutor acts as the coroner this standard cannot possibly be met. See Standards for Crim. Just. Prosecution Function \& Def. Function r. 3-3.3 (AM. BAR ASS'N 1992).

110299 N.W. 378 (Neb. 1941).

111 Id. at 383 .

${ }^{112} I d$. The court noted the legislative intent to provide efficiency and cost savings. $I d$. at 382 .

${ }^{113}$ McKinney v. Okoye, 806 N.W.2d 571, 578 (Neb. 2011).

114 WASH. REV. CODE ANN. § 36.16.030 (West 2003 \& Supp. 2018) (“"I]n each county with a population of less than forty thousand no coroner shall be elected and the 
requiring the prosecutor to serve as coroner eliminates the independence that safeguards the fair outcome of death investigations.

While it may make superficial sense for cities with fewer resources and smaller budgets to combine the role of prosecutor and coroner, ${ }^{115}$ the greater concern for justice outweighs the relatively modest savings provided by combining the roles. ${ }^{116}$ Efficiency and cost savings should not be pursued at the expense of a thorough and accurate death investigation.

\section{One Party or Both Parties Knowingly Act Due to an Obvious Conflict of Interest}

In addition to the conflicts of interest that are apparent when a prosecutor serves as coroner, there are opportunities for overt conflicts of interest between prosecutors and death investigators even while serving in their individual capacities. An overt conflict of interest exists when, at the time of the interactions between the death investigator and the prosecutor, one or both parties knowingly act due to inappropriate influence. ${ }^{117}$ These conflicts manifest in situations in which a prosecutor actively pressures an investigator to change or conceal the results of an investigation. ${ }^{118}$ In turn, the death investigator knowingly compromises his or her duty and objectivity in support of the prosecution. Further, prosecutors and death investigators may actively work together to achieve a more favorable outcome for the prosecution. ${ }^{119}$ These cases reflect situations in which both offices allow competing interests and loyalties to cloud their independent and professional judgment.

In State v. Beecroft, ${ }^{120}$ there was no dispute over whether the defendant had stabbed her newborn infant and put the baby in the trash; the question

prosecuting attorney shall be ex officio coroner."). Once the population of a county attains forty thousand, the coroner must be elected. Id.

115 Skamania County Coroner, supra note 104.

116 See Medicolegal DeAth InVESTIGATION SySTEM, supra note 10, at 26 (noting the potential of coroners lacking knowledge or having conflicts of interest, "especially when funeral directors, prosecutors or sheriffs act as coroners").

117 See Jennifer E. Laurin, Remapping the Path Forward: Toward a Systemic View of Forensic Science Reform and Oversight, 91 TEX. L. REV. 1051, 1068 (2013) (highlighting the need for medical examiner independence from law enforcement agencies in order to reduce conflicts of interest).

${ }^{118}$ See id. at 1055 (discussing the ways in which a prosecutor can influence a death investigation, such as influencing death investigator priorities and investigation techniques).

${ }^{119}$ For a modern example of a death investigator changing his results based on the opinion of the prosecutor, see Patricia Wen, Medical Examiners Here Can Be a Jury of One, Bos. GloBe (Aug. 20, 2016), https://www.bostonglobe.com/metro/2016/08/20/lifeand-death-decision-without-supervision/gRzxpXjWQ0gHY2y49Nb8LK/story.html [https://perma.cc/CUT6-KAZ9] (highlighting the potential for conflicts of interest when the death investigator and prosecutor work closely and the lack of oversight for death investigations).

120813 N.W.2d 814 (Minn. 2012). 
instead was whether the infant had been born alive or dead. ${ }^{121}$ The prosecution maintained the former, making the horrific scene a murder. ${ }^{122}$ With blind ambition, the prosecution intimidated the defense team's death investigators, preventing them from testifying in opposition to the prosecution's theory. ${ }^{123}$ The prosecution materially affected the outcome of the case by limiting the defense team's access to resources and qualified death investigators, and by threatening to dismantle the investigator's career and blackmail her supervisors. ${ }^{124}$ Since the prosecutor was willing to compromise his integrity and the independence of his office, he made the defense team's experts so fearful for their "professional and financial well-being," Beecroft was denied a fair and just trial. ${ }^{125}$

Intimidating death investigators because their testimony conflicts with the prosecution's theory is an obvious conflict of interest. These issues are exacerbated by the very structure of the death investigation system that allows for the power of the prosecutor to go unchecked. The nature of the adversary system is inherently contentious and matches competing experts against one another. Both the prosecution and the defense should have equal access to qualified and competent death investigators; in reality, however, the death investigation system gives the prosecution a clear advantage. Allowing a prosecutor to intimidate death investigators and experts, without repercussion, not only chills what is intended to be an independent and adversarial system, but also promotes faulty forensic science.

The structural and independence issues raised in Beecroft are further exemplified through acts of collusion between prosecutors and death investigators. In Rivas $v$. Fischer, ${ }^{126}$ a prosecutor and death investigator colluded to produce a time of death that favored the prosecution's theory of a murder. ${ }^{127}$ The prosecution could not prove its case unless the death investigator reexamined the autopsy report "with an eye toward expanding the time of death."128 The investigator was motivated to please the prosecutor, perhaps because the investigator hoped that his compliance would lead to the

121 Id. at 824 .

122 Id.

${ }^{123}$ Id. at 826-30; see also Julie Jonas, True Independence for Medical Examiners Equals Due Process for Criminal Defendants and More Efficiencies in the Criminal Justice System, 37 WM. MitcheLl L. REV. 698, 712-13 (2011).

${ }^{124}$ The prosecutor emailed the investigator's superior to say that it was unacceptable for the investigator staff to testify for the defense team and that he would not support the supervisor's campaign for coroner if the staff continued to testify. Beecroft, 813 N.W.2d at $827-28$. The prosecutor threatened to file a complaint against the death investigator with the state agency and to keep her from ever teaching again at the state crime laboratory. Id.

$125 \mathrm{Id}$. at 840 .

126687 F.3d 517 (2d Cir. 2012).

$127 \mathrm{Id}$. at 528 .

128 Id. at 521. "No matter how much circumstantial evidence the prosecution could amass tending to link Rivas to the crime, however, it had no case unless it could prove that [the victim] died [within the new timeframe]." Id. at 524. 
dismissal of a pending criminal misconduct charge against him. ${ }^{129}$ Situations like this, in which a prosecutor actively and inappropriately engages a death investigator to skew the autopsy findings in order to secure a conviction, create clear conflicts of interest. Contrary to the purposes of the death investigation system-including independence, objective outcomes, and justice - death investigators are motivated to please prosecutors in order to sustain business. Stretching science beyond a factual and accurate point only produces a skewed and subjective system.

Inappropriate relationships between the death investigator and the prosecutor often go unnoticed and, therefore, unsanctioned. When discovered, however, the relationship provides a disturbing insight into how pervasive collusion may be. ${ }^{130}$ In Mitchell $v$. Gibson, ${ }^{131}$ for example, the death investigator, Joyce Gilchrist, ${ }^{132}$ worked with the prosecutor to hide exculpatory evidence from the defense counsel, leading to a wrongful conviction and a sentence of death. ${ }^{133}$ Gilchrist knowingly gave false and misleading testimony that DNA found on the victim matched that of the defendant, permitting the prosecutor to obscure the truth and blind the jury from contradictory reports to secure a conviction. ${ }^{134}$ Gilchrist's unbridled control over the medical evidence, combined with the prosecutor's ability to capitalize on his close relationship with her, created a space for inappropriate influence and misconduct. ${ }^{135}$ The post-conviction trial court described this conduct as "absolutely indefensible"; 136 the appellate court stated that it "strikes a heavy blow to the public's 'trust in the prosecutor." 137 The court granted a conditional writ of habeas corpus and invalidated Mitchell's death sentence on due process grounds. ${ }^{138}$

While the factors contributing to overt conflicts of interest described above illuminate serious issues in the criminal justice system at large, they are only part of the problem. In addition to outright collusion and intimidation tactics, it

${ }^{129}$ See id. at 528 (stating that the defendant alleged that the medical examiner altered the time of death to avoid prosecution for a pending misconduct charge).

${ }^{130}$ See Chesher v. Neyer, 477 F.3d 784, 792 (6th Cir. 2007) (describing how the closeness of the prosecutor and death investigator's offices led to an attempt to cover up a death investigator's illegal activity); Williams v. Hartje, 827 F.2d 1203, 1205 (8th Cir. 1987) (alleging that the coroner and prosecutor worked together to conceal an autopsy report from the defense team); Ellingson v. Piercy, No. 2:14-CV-04316-NKL, 2015 U.S. Dist. LEXIS 76703, at *9-11 (W.D. Mo. June 15, 2015) (discussing the potential cover-up among the death investigator, the prosecutor, and the police department when the death investigator failed to disclose all toxicology reports).

131262 F.3d 1036 (10th Cir. 2001).

132 For further discussion concerning Gilchrist, see infra Part II.B.1.

133 Mitchell, 262 F.3d at 1060.

${ }^{134}$ Id.

135 Gershman, supra note 91 , at 33.

136 Mitchell, 262 F.3d at 1060.

137 Id. at 1064.

138 See id. at 1066. 
is an overt conflict of interest when a prosecutor knowingly elicits false testimony from a death investigator. In Drake v. Portuondo, ${ }^{139}$ a jury convicted the defendant on two counts of second-degree murder based largely on the prosecution's false testimony from an expert witness. ${ }^{140}$ The prosecution team knew that it lacked evidence of motive, so they called a psychologist at the last minute ${ }^{141}$ to testify about a so-called medical theory known as "picquerism." 142 The prosecution delayed notifying the defense team about the additional witness the weekend before trial, thus giving the defense minimal time to evaluate the witness and produce its own expert. ${ }^{143}$ Furthermore, the prosecutor "did not independently investigate [the expert's] credentials or contact any other mental health professional to inquire about picquerism" before putting him on the stand. ${ }^{144}$

While a prosecutor should zealously seek a conviction, he or she should not ignore evidence or testimony that is not grounded in facts or supported by accurate and credible scientific evidence. The prosecutor in Drake knew that picquerism was not a legitimate medical theory; nevertheless, he solicited the investigator's testimony to win the case. ${ }^{145}$ The prosecutor elicited false testimony to establish motive, and the investigator lied about his credentials and provided false testimony. ${ }^{146}$ When a prosecutor and the death investigator act for personal or professional gain, it creates a serious conflict of interest.

Similarly, in Miller v. Pate, ${ }^{147}$ the prosecutor knowingly elicited, and the death investigator willingly provided, false testimony to support the prosecution's argument. ${ }^{148}$ The prosecutor pursued a case theory that focused on a pair of blood-stained shorts that were found near the crime. ${ }^{149}$ He claimed the shorts tied the defendant to the murder of an eight-year-old girl. ${ }^{150}$ The death investigator intentionally lied on the stand by asserting that the shorts

139553 F.3d 230 (2d Cir. 2009).

$140 I d$. at 233.

${ }^{141} \mathrm{Id}$.

142 Id. at 235 (defining picquerism as "a purported syndrome or criminal profile in which the perpetrator realizes sexual satisfaction from penetrating a victim by sniper activity or by stab or bite wounds"). The prosecutor knew that picquerism was not a legitimate medical theory and intentionally elicited the death investigator's testimony about his unsubstantiated theory and his false testimony about his involvement in the case. $I d$. at 243.

${ }^{143}$ See id. (noting that the prosecution gave the defense only one day's notice of its intent to call the death investigator).

${ }^{144} I d$. at 235.

145 Drake, 553 F.3d at $243-44$.

${ }^{146}$ See id. at 238-39; see also Charles Patrick Ewing, False Credentials Cause Extensive Fallout, 34 MONITOR ON PSYCHOL. 84 (2003) (describing how the death investigator's false credentials contributed to the unfortunate outcome of the case and encouraging prosecutors to carefully vet their experts' résumés).

147386 U.S. 1 (1967) (unanimous opinion).

${ }^{148} I d$. at 6-7.

${ }^{149} I d$. at $3-4$.

${ }^{150} \mathrm{Id}$. 
were stained with Type A blood, the victim's blood type, rather than Type O blood, the defendant's blood type. ${ }^{151}$ The prosecution did not allow the defense team to test the shorts, which gave the prosecutor and the death investigator exclusive control over key medical evidence. ${ }^{152}$ As a result of the prosecutor's and investigator's repeated lies and misstatements, the jury found the defendant guilty and sentenced him to death. ${ }^{153}$ The case was ultimately appealed to the Supreme Court, where it became evident that the shorts were stained with paint, rather than blood, and that the prosecutor, the investigator, and nearly everyone on the government's side knew at trial that the shorts did not have blood stains. ${ }^{154}$ The prosecutor and the death investigator had colluded by repeatedly misconstruing and lying about the key medical evidence.

Whether prosecutors actively approach a death investigator, or the two offices conspire, the foregoing cases demonstrate how pervasive overt conflicts of interest are throughout the criminal justice system. Until steps are taken to reform and implement oversight in the existing system, this type of conflict of interest between death investigators and prosecutors will continue. More broadly, a system that gives prosecutors exclusive control over death investigators and their scientific findings creates serious doubt that prosecutors will appropriately manage non-scientific evidence such as confessions and eyewitness testimony. ${ }^{155}$

\section{B. Discreet and Non-Obvious Conflicts of Interest}

While overt conflicts of interest are detrimental to the justice system, most conflicts result from more discreet and subtle circumstances. These conflicts tend to occur when one party is not fully aware that his or her decisions are motivated by competing pressures and improper influence. ${ }^{156}$ The death investigation structure allows investigators and prosecutors to develop a close working relationship, allows them to work in the same building, and permits

${ }^{151} I d$. at 4, 6 (explaining that the prosecutor knew the entire time that he had presented false evidence and "deliberately misrepresented the truth").

152 Miller, 386 U.S. at 5.

$153 \mathrm{Id}$. at 2.

${ }^{154}$ See id. at 6-7.

155 Gershman, supra note 91, at 18.

Clearly, if a prosecutor bent on winning at all costs is able to manipulate technical and seemingly objective "scientific" evidence, how much more likely is it that the prosecutor will be able to misuse more subjective and easily manipulated nonscientific evidence such as confessions to police, eyewitness identifications, and the testimony of informants, accomplices, and jailhouse "snitches?"

Id.

${ }^{156}$ See A PATH FORWARD, supra note 37, at 185 (recognizing that improper influence can manifest in a pro-prosecution bias); CONFLICTS OF INTEREST, supra note 85, at 3. 
both offices to promote a similar agenda. ${ }^{157}$ Over time, prosecutors exert subtle influence over death investigators and gain privileged access that defense teams are routinely denied. ${ }^{158}$

After years of working together and developing a rapport, death investigators begin to view themselves as part of the prosecution team and may develop a pro-prosecution bias, which is contrary to the goals of an independent death investigation system. ${ }^{159}$ This in-group bias causes death investigators to shape results to help prosecutors and leads prosecutors to capitalize on that bias. ${ }^{160}$ To understand how underlying pressures lead death investigators to compromise their independence and objectivity, it is necessary to examine the careers of some infamous offenders. By examining a death investigator's career, it is easy to see how the constant underlying pressure and close relationship with prosecutors can cause a gradual shift in objectivity and how, in the long run, these characters become oblivious to such implicit biases.

\section{Joyce Gilchrist}

Perhaps one of the most notable characters in the death investigation system who exemplifies the issue of pro-prosecution bias resulting in conflicts of interest is Joyce Gilchrist. ${ }^{161}$ Throughout her career, Gilchrist worked solely with prosecution teams as a death investigator, conducting investigations and serving as an expert witness. ${ }^{162}$ Over time Gilchrist developed what seemed to be a pattern of delaying evidence, severely disadvantaging defense teams, and testifying beyond the scope of her knowledge; all of her tactics appeared to

157 See generally Bruce A. Green \& Fred C. Zacharias, Prosecutorial Neutrality, 2004 WIS. L. REV. 837, 849-56 (2004) (arguing that inherent conflicts of interest exist when offices with varying incentives work closely together).

158 See, e.g., Paul C. Giannelli, The Abuse of Scientific Evidence in Criminal Cases: The Need for Independent Crime Laboratories, 4 VA. J. Soc. PoL'Y \& L. 439, 473-74 (1997) (explaining that for most defendants it is difficult to obtain defense experts).

${ }^{159}$ See Conor Friedersdorf, CSI Is a Lie, ThE ATLANTIC (Apr. 20, 2015), http://www.theatlantic.com/politics/archive/2015/04/csi-is-a-lie/390897/ [https://perma.cc/ NJ5A-JH3L] (stating that "medical examiners ... typically work for the government and are generally seen as part of the prosecution's 'team,' much like the police and investigators").

${ }^{160}$ See Gershman, supra note 91, at 31. In fact, a culture of "winning at all costs" may push prosecutors to misuse and manipulate evidence and testimony. Id. at 18.

161 See Paul C. Giannelli \& Kevin C. McMunigal, Ethical Considerations in the Use of Expert Testimony: Prosecutors, Ethics, and Expert Witnesses, 76 FordHAM L. REV. 1493, 1498 (2007) (describing Gilchrist as an example of a "corrupt expert"); Belinda Luscombe, When the Evidence Lies, TIME (May 13, 2001), http://content.time.com/time/magazine/ article/0917110962500.html [on file with Ohio State Law Journal] (reporting on Gilchrist's infamous cases as a forensic scientist with the Oklahoma City police department).

162 See Luscombe, supra note 161 (describing several instances in which Gilchrist's findings were called into question for their accuracy). 
favor the prosecution. 163 Gilchrist repeatedly disobeyed court orders to conduct tests that could have cleared defendants and failed to turn over evidence to defense teams. ${ }^{164}$ Moreover, prosecutors knew or should have known that Gilchrist's testimony and work were inaccurate. Despite her extensive history of misconduct and bias, however, they still chose to employ her as an expert because her pattern of behavior was an asset to prosecution teams. ${ }^{165}$

These conflicts of interest resulted from improper influence and the inappropriate relationship between Gilchrist's office and the prosecution team. Her legacy includes false testimony regarding medical evidence, false imprisonment of innocent defendants, and possibly even the execution of innocent people. ${ }^{166}$ By exploiting Gilchrist's pro-prosecution bias, prosecution teams undermined their responsibility to the justice system. Gilchrist's actions shed light on how discreet conflicts of interest manifest over time and are the result of gradual influence creating an inherent bias, rather than manifesting as an overt attempt to advantage prosecutors. ${ }^{167}$ When death investigators, such as Gilchrist, experience pressure from prosecutors or are made to feel part of the prosecution team, each office's independence is compromised.

163 See generally Miller v. State, 809 P.2d 1317 (Okla. Crim. App. 1991) (involving Gilchrist in a non-death investigation case); Pierce v. State, 786 P.2d 1255 (Okla. Crim. App. 1990) (same); McCarty v. State, 765 P.2d 1215, 1217-19 (Okla. Crim. App. 1988) (highlighting Gilchrist's behavior of delaying evidence and testifying beyond her qualifications in a death investigation case).

${ }^{164}$ A prime example of Gilchrist's transgressions is exemplified in McCarty v. State, 765 P.2d 1215 (Okla. Crim. App. 1988). Gilchrist delayed testing evidence for a firstdegree murder conviction for four years and did not finish her examination until the Friday before a Monday trial, precluding the defense team from obtaining an independent review of her findings. $I d$. at 1217 . This delay appeared to be a strategy to aid the prosecution's theory and disadvantage the defense team. Further, she went on to discredit any independent examinations that the defense team could find, stating that they could not possibly have had time to properly examine the evidence. Id. at 1217-18. In addition, she stated at trial that, although she was unqualified to give an opinion about whether the appellant was at the scene of the crime, the DNA evidence showed that he was, in fact, there. Id. at 1218-19. The court found that the County's District Attorney's Office placed undue pressure on Gilchrist to give an expert opinion beyond the scope of her knowledge; that led to prosecutorial comments "so prejudicial as to adversely affect the fundamental fairness and impartiality of the proceedings." Id. at 1219 n.1, 1221. After this trial, a formal complaint of misconduct was filed against Gilchrist, but no disciplinary action was taken. Id. at 1219 .

165 Giannelli \& McMunigal, supra note 161, at 1501 ("Given the many signals that her testimony was corrupt, prosecutors should have stopped using her as a witness. .. . '[T]he district attorney's office loved having her as a witness."').

166 To add gravity to this issue, twenty-three of the cases Gilchrist worked on were death penalty cases, eleven of which have led to execution. Now there is no way to re-test Gilchrist's results, possibly exonerating any innocent defendants. See Luscombe, supra note 161 .

${ }^{167} \mathrm{See} i d$. (reporting on Gilchrist's bewilderment that people have negative perceptions of her work as a death investigator). 


\section{Fred Zain}

A "super star" who could find evidence when no one else could and always gave prosecutors a win, death investigator Fred Zain's experience highlights how pro-prosecution bias corrupts the system and how untrustworthy scientific evidence is endemic. While Zain appeared to be a scientific genius to some people, he turned out to be a massive fraud who falsified results in as many as 134 cases. ${ }^{168}$ Zain may have been driven by a distorted sense of justice to help prosecutors, criticizing other death investigators for being too conservative when examining evidence. His "talent," however, only hurt defendants and victims. Inadvertent errors and exaggeration may seem like negligible nudges that help the prosecution, but they are actually measured actions that can add up to massive fraud. Compounding the effects of Zain's errors, prosecutors capitalized on his results and never questioned those results that favored their side. ${ }^{169}$

Even more concerning than Zain's conduct is that the system allowed these conflicts to occur and remain unchecked. When Zain should have presented accurate and reliable scientific evidence, his relationship with prosecutors and his underlying bias pushed him to find what other death investigators could not. Because prosecutors and investigators are able to form a close working relationship, the line of independence is blurred, leading investigators such as Zain to present fraudulent pseudo-science as credible. The system accepts forensic evidence as proffered by experts; and without placing checks on how evidence is examined or presented, conduct like Zain's

168 See Paul C. Giannelli, Wrongful Convictions and Forensic Science: The Need to Regulate Crime Labs, 86 N.C. L. REV. 163, 172 (2007).

The acts of misconduct on the part of Zain included (1) overstating the strength of results; (2) overstating the frequency of genetic matches on individual pieces of evidence; (3) misreporting the frequency of genetic matches on multiple pieces of evidence; (4) reporting that multiple items had been tested, when only a single item had been tested; (5) reporting inconclusive results as conclusive; (6) repeatedly altering laboratory records; (7) grouping results to create the erroneous impression that genetic markers had been obtained from all samples tested; (8) failing to report conflicting results; (9) failing to conduct or to report conducting additional testing to resolve conflicting results; (10) implying a match with a suspect when testing supported only a match with the victim; and (11) reporting scientifically impossible or improbable results.

Id. at $172-73$.

169 Giannelli \& McMunigal, supra note 161, at 1497 (“'[O]ne serologist 'testified that at least twice after Zain left the lab, evidence on which [the serologist] had been unable to obtain genetic markers was subsequently sent to Texas for testing by Zain, who again was able to identify genetic markers."'). 
can result in a "systematic practice rather than an occasional inadvertent error." 170

\section{Dr. Steven Hayne}

Another example of how pro-prosecution bias corrupts the system is Dr. Steven Hayne, who fabricated medical evidence and case theories in favor of the prosecution. ${ }^{171}$ Dr. Hayne consistently came up with outlandish methods and theories that aided the prosecution. For example, he replicated gunpowder marks by test-firing on canine skin in order to determine the distance between the shooter and the victim; he also compared teeth marks in a partiallydigested bologna sandwich to a suspect's mouth. ${ }^{172}$ Not only did Dr. Hayne fabricate theories, but he also performed $257 \%$ more autopsies than allowed by the National Association of Medical Examiners (NAME), which severely affected the quality of his work. ${ }^{173}$

While Dr. Hayne is not innocent in his involvement in the foregoing incidents, his actions represent a larger problem in the death investigation system. Abuse of death investigator findings "are not unique to Mississippi, and are able to persist because scientific testimony is too often viewed with uncritical reverence and because the people affected by its misuse usually have

${ }^{170}$ Kathleen Keough Griebel, Fred Zain, the CSI Effect, and a Philosophical Idea of Justice: Using West Virginia as a Model for Change, 114 W. VA. L. REV. 1155, 1185 (2012).

${ }^{171}$ One of the most glaring examples involved Dr. Hayne creating a two-shooter theory to the exclusion of a single-shooter theory. Edmonds v. State, 955 So. 2d 787, 791 (Miss. 2007). This fabricated explanation directly aligned with the prosecution's theory of the case. Id. at 792. The Mississippi Supreme Court found that Dr. Hayne's testimony was not based on scientific methods and, pursuant to the court's standards, that the two-shooter theory should not have been admitted at trial. Id. See generally K.C. Meckfessel Taylor et al., CSI Mississippi: The Cautionary Tale of Mississippi's Medico-Legal History, 82 Miss. L.J. 1271 (2013) (discussing the problems in Mississippi's death investigation system, with a specific focus on Dr. Hayne's misdeeds); Radley Balko, Steven Hayne, Michael West 'Expert' Witness Scandal Could Affect Mississippi Attorney General Race, HuFFPost (Aug. 28, 2011), http://www.huffingtonpost.com/radley-balko/steven-hayne-michael-westforensic-scandal_b_940767.html [https://perma.cc/AC47-2TAW] (describing Dr. Hayne as a "gun[] for hire, willing to say on the witness stand whatever prosecutors need in order to win a conviction").

172 See Meckfessel Taylor et al., supra note 171, at 1290-93 (describing the various outlandish techniques that Dr. Hayne employed in his work).

${ }^{173} I d$. at 1281 . Dr. Hayne's workload was so egregious that in one case he completed a report on a spleen that had been removed from the body years earlier. Id. at 1282-83. In a recently published book that is highly critical of the Mississippi death investigation system and Dr. Hayne in particular, one of the authors wrote: "Until and unless the state engages in a thorough, top-down investigation of [his] work, we may never know the extent of the damage [he] may have done. So far, the people with the power to initiate such an investigation haven't shown much interest." RADLEY BALKO \& TUCKER CARRINGTON, THE Cadaver King and the Country Dentist: A True Story of InJustice in the AMERICAN SOUTH Xvi (2018). 
little support or sympathy."174 A system that allows for both overt and nonobvious conflicts of interest cries out for change.

\section{RECOMMENDATIONS}

The current structure of the death investigation system and the ways in which it is intertwined with the criminal justice system is susceptible to conflicts of interest that inhibit the fair and effective administration of justice. These conflicts, both overt and discreet, are caused by the inadequate oversight of officials and the unregulated working relationships between death investigators and prosecutors. While the potential for conflicts may never be entirely eliminated due to of the repeat nature of the actor's interactions, steps can be taken to reduce conflicts substantially. True independence is necessary in order to restore the separate and distinct goals of each office. To prevent circumstances in which death investigators present exaggerated or tainted science and testimony, the system must implement strict education and accreditation requirements. Achieving these important goals depends on the establishment of a pure medical examiner system and a federal agency to oversee and balance the relationship between death investigators and prosecutors.

Curbing conflicts and potential abuses means divorcing the death investigators' offices from the prosecutors' offices. The structure of the death investigation system provides prosecutors with privileged access to forensic evidence and allows them to influence death investigators, ultimately substantially disadvantaging criminal defense teams. Permitting prosecutors and death investigators to be housed under the same governmental framework - inducing death investigators to feel part of the prosecution team and even allowing both entities to occupy the same space-compromises their independence. ${ }^{175}$ Without real independence, death investigators will remain under the authority of prosecutorial agencies, subject to administrative and political pressure. ${ }^{176}$ Independence thus requires providing death investigators with their own space, allowing defense teams equal access to medical experts and evidence, and introducing oversight to hold prosecutors accountable. By removing death investigators from the umbrella of the prosecutor, death investigators can focus on providing objective and accurate medical evidence. Ensuring independence may require more collaboration between prosecutors

${ }^{174}$ Campbell Robertson, Questions Left for Mississippi Over Doctor's Autopsies, N.Y. TIMES (Jan. 7, 2013), http://www.nytimes.com/2013/01/08/us/questions-for-mississippidoctor-after-thousands-of-autopsies.html [on file with Ohio State Law Journal] (describing the negative perceptions toward criminal defendants by both prosecutors and society at large).

175 See generally Laurin, supra note 117, at 1052-54.

176 See Medicolegal Death InVESTigation System, supra note 10, at 33; Laurin, supra note 117, at 1065 (stating that death investigators and crime laboratories should be independent from administrative and prosecutorial control). 
and death investigators, but the need for objectivity outweighs the "thoughtful calibration" required to guarantee independence. ${ }^{177}$

Improving the accuracy of the death investigation system also requires strengthening educational requirements and training for death investigators. At present, there is no uniform curriculum or consensus of what educational requirements should guide death investigators, even within an individual state system. The result is a fragmented death investigation system. ${ }^{178}$ With current death investigation offices overwhelmed with a backlog of autopsies, ${ }^{179}$ a system without a standardized educational baseline could mean that the innocent get convicted or the guilty go free. The foundation for a competent and accurate death investigation system starts with knowledgeable and trained professionals to staff each office. The lack of real training and education, however, means that the burden of developing competent death investigators falls to on-the-job training, which is often insufficient due to the cycle of undereducated and undertrained professionals currently working in these offices. ${ }^{180}$

Establishing mandatory accreditation and certification processes for death investigators can further improve the reliability and accuracy of medical evidence. Currently, accreditation and certification are voluntary efforts by death investigation offices to follow recommended standards that establish quality control measures and death investigator proficiency. ${ }^{181}$ Mandatory

177 See Laurin, supra note 117, at 1112.

178 See Felder, supra note 35, at 643-44 (explaining that the gaps and issues in Louisiana's death investigation system resulted from inadequate education and training requirements); see also supra Part I.A.2.

${ }^{179}$ Katharine Q. Seelye, As Overdose Deaths Pile Up, a Medical Examiner Quits the Morgue, N.Y. TIMES (Oct. 7, 2017), https://www.nytimes.com/2017/10/07/us/drugoverdose-medical-examiner.html [https://perma.cc/T3ZT-ETVV] (highlighting the opioid epidemic and the "tsunami" of bodies needing autopsies and creating a backlog for death investigation offices across the country).

${ }^{180}$ Randolph N. Jonakait, Forensic Science: The Need for Regulation, 4 HARV. J.L. \& TECH. 109, 124-27 (1991) (discussing how poor education and training are pervasive issues in the forensic science field). Compounding this issue is the lack of interest in forensic science and death investigation. To help meet these requirements, states should improve undergraduate and graduate forensic science programs and create incentives for students to pursue these fields through scholarships and fellowships. See A PATH FORWARD, supra note 37, at 27-28 (noting that improved education programs will help "correct some of the existing deficiencies" of the death investigation system). "Federal crime labs (97\%) were more likely than state (83\%), municipal $(75 \%)$, and county $(51 \%)$ labs to have written standards for performance in 2014." Andrea M. Burch et al., BUREAU of Justice Stat., U.S. Dep'T of Justice, NCJ 250152, Publicly Funded Forensic LABORATORIES: QUALITY ASSURANCE PRACTICES, 2014, 5 (2016), available at https://www.bjs.gov/content/pub/pdf/pffclqap14.pdf.

181 The National Association of Medical Examiners (NAME) prepares and sets accreditation standards to help improve the quality of death investigations. See Inspection and Accreditation, NAT'L ASS'N MED. EXAMINERS, https://netforum.avectra.com/eweb/ 
accreditation and certification would ensure that death investigation offices are effectively managed and that only qualified individuals have dominion over medical evidence. ${ }^{182}$ Accreditation would require an impartial third party to determine whether an office meets the established quality control measures. ${ }^{183}$ Certification would require an individual to prove that he or she is qualified and obtained the necessary education and training. ${ }^{184} \mathrm{~A}$ regime that requires knowledgeable professionals and competent offices buttresses the entire justice system.

In addition to strengthening qualifications for individual death investigators, instituting a nationwide medical examiner system would ensure that deaths are evaluated by qualified medical professionals, would create more uniform requirements, and would reduce conflicts of interest that pervade the system. This shift requires abolishing the coroner system. Many coroners are unprepared and incapable of meeting the basic goal of a death investigation: assessing the cause, timing, and manner of a suspicious or unexplained death. ${ }^{185}$ Coroners are often elected without any medical education or expertise and are therefore unqualified to perform the duties of the position. ${ }^{186}$ Not only are some coroners underqualified, but some also have misconceptions about the value and purpose of their role and may be motivated by reelection and a desire to please stakeholders or superior

DynamicPage.aspx $?$ Site $=$ name $\&$ WebCode $=$ Accred

[https://perma.cc/W4LY-7BYY]. These standards apply to offices and systems, rather than to individuals, and provide minimum standards to which the systems should comply. Id. The NAME standards are voluntary, however, and merely represent an endorsement by the association that the accredited system or office meets NAME's standards. Id.

182 See Exec. Office OF THE President \& NAT'L SCI. \& TeCh. Council, StRENGTHENING THE MEDICOLEGAL-DEATH-INVESTIGATION SYSTEM: ACCREDITATION AND CERTIFICATION-A PATH FORWARD 2 (2016) [hereinafter ACCREDITATION AND

CERTIFICATION], available

at https://obamawhitehouse.archives.gov/sites/default/files/microsites/ostp/NSTC/strengtheni ng_the_medicolegal_death_investigation_system_final.pdf $\quad[\mathrm{https}: / /$ perma.cc/D7VN2CYR].

${ }^{183} I d$. at $2-3$. The two premier crime lab accreditation organizations are the American Society of Crime Lab Directors/Laboratory Accreditation Board, International (ASCLD/LAB, International) and Forensic Quality Services-International (FCSInternational). As of $2014,66 \%$ of municipal and $78 \%$ of county crime labs, as compared with $97 \%$ state and $67 \%$ federal crime labs, were accredited by the ASCLD or FCSInternational. Burch, supra note 180 , at $2-3$ \& tbl.1.

184 ACCREDITATION AND CERTIFICATION, supra note 182, at 3. In 2014, 5\% of municipal and $8 \%$ of county crime labs, as compared with $7 \%$ of state and $39 \%$ of federal crime labs, tested the proficiency of forensic personnel through blind examinations. Additionally, federal crime labs were more likely to conduct random case reanalysis than publicly funded labs in other jurisdictions. Furthermore, during 2014, 72\% of crime labs employed at least one externally certified analyst. Burch, supra note 180, at 4-5.

${ }^{185}$ See Medicolegal DeAth InVESTigation System, supra note 10, at 29-30 (discussing the hesitation and inability of coroners to conduct autopsies compared to medical examiners in cases such as heart attacks, burned bodies, and possible homicides).

186 A PATH FORWARD, supra note 37, at 49. 
government officials. ${ }^{187}$ An electoral system rife with conflicts of interest and misconduct makes medical examiners the preferred choice of death investigators. ${ }^{188}$ Furthermore, evaluating the cause of death is a medical determination that requires a medical professional. ${ }^{189}$ Medical examiners, unlike coroners, are qualified to conduct autopsies and, because of their extensive medical education, they know what is medically plausible; they are more likely, therefore, to question what may appear to be a natural death. ${ }^{190}$ Finally, medical examiners are the preferred death investigator because they are hired, rather than elected officials. ${ }^{191}$ For these reasons, according to one knowledgeable commentator, “[ $t$ ] he coroner system isn't just an anachronism; it's an anachronism that never made much sense in the first place. It's well past time to get rid of it."'192

An independent, science-based, uniform death investigation system is dependent on the creation of a federal agency or an office within an existing agency to oversee the death investigation system. ${ }^{193}$ This federal agency would implement national standards for death investigators, require sciencebased death investigations, develop regulations for managing misconduct, and implement incentives to encourage medical students to enter the pathology field, ultimately improving the accuracy and reliability of death

${ }^{187}$ In a New York county coroner race, for example, candidates were interviewed about why they were running for the position. All of the candidates indicated that they wanted to help grieving families, rather than solve and explain mysterious and suspicious deaths. See Sarah Harris, Run for Coroner, No Medical Training Necessary, NPR (Nov. 3, 2013), http://www.npr.org/2013/11/03/242416701/run-for-coroner-no-medical-trainingnecessary [https://perma.cc/H8SX-8F6M].

188 See Associated Press, Ex-Coroner: Elected System Can Mean Conflicts of Interest, WASH. TIMES (June 7, 2015), [hereinafter Ex-Coroner] http://www.washingtontimes.com/ news/2015/jun/7/ex-coroner-elected-system-can-mean-conflicts-of-in/

[https://perma.cc/49SF-VUVM] (asserting that coroners should be appointed rather than elected, due to conflicts of interests between coroners and funeral directors).

189 Pearsall, supra note 58.

190 See Medicolegal Death InVestigation System, supra note 10, at 30. For example, a medical examiner is more likely than a lay coroner to conduct an autopsy in a case in which a 30-year-old died from an alleged heart attack. Id. The medical examiner would be more inclined to do an autopsy because the medical examiner would know that this cause of death was medically implausible. $I d$.

${ }^{191}$ Id. at 25; see also Ex-Coroner, supra note 188 (asserting that coroners should be appointed rather than elected because of conflicts of interests between coroners and funeral directors). Opponents of this position may argue that elections are beneficial because they give coroners autonomy to take positions that are in line with their constituents, rather than be pressured by other elected officials. See Medicolegal Death InVEstigation System, supra note 10 , at 26 .

192 Balko, supra note 105.

193 A Path Forward recommended that a new federal agency should be created because existing agencies do not have the bandwidth or the "appropriate mission" to take on issues related to the forensic science community. See A PATH FORWARD, supra note 37, at 18 . The report noted that agencies that are already working on forensic science issues should continue those projects. $I d$. 
investigations. ${ }^{194}$ Federal regulation and oversight would eliminate the existing patchwork of laws that govern death investigations at the state and local level. Holding all death investigators accountable under the federal standard would deter misconduct and reduce the misuse of scientific data. ${ }^{195}$

While a federal death investigation system would improve the integrity and accuracy of death investigations, it could also promote information sharing between other agencies. ${ }^{196}$ For example, the National Highway Traffic Safety Administration uses death investigation data to monitor trends in traffic related accidents, and the CDC and the Food and Drug Administration use data to monitor trends in drugs and diseases. A federal system would create an information sharing database among the federal government, states, and localities, thus providing comprehensive death statistics and, in turn, helping underfunded and understaffed offices direct resources appropriately. ${ }^{197}$

\section{CONCLUSION}

The death investigation system in the United States has evolved over time, growing out of centuries-old traditions in England. But this outdated framework has not kept pace with changing societal values and scientific advances. The current system is fragmented and inconsistent across county and state lines, leading to situations like Justice Scalia's death in which local laws can reduce an investigation having national and political implications to a telephone call. ${ }^{198}$ This Article does not mean to imply foul play in Justice Scalia's death; rather, the death-assessment practices established in the small

194 See EXEC. OfFice OF THE PRESIDENT \& NAT'L SCI. \& TECH. Council, STRENGTHENING THE MEDiCOLEGAL-DEATH-INVESTIGATION SYSTEM: IMPROVING DATA SYSTEMS 1 (2016), https://obamawhitehouse.archives.gov/sites/default/files/microsites/ ostp/NSTC/strengthening_the_medicolegal_death_investigation_system_final.pdf.

${ }^{195} \mathrm{Id}$. Ethical codes instruct analysts on best practices and ensure that analysts work within the confines of their expertise, provide objective findings, avoid conflicts of interest, and prevent susceptibility to outside influences. Burch, supra note 180, at 5. During 2014, state crime labs (98\%) were more likely to have a written code of ethics than county $(94 \%)$, municipal (87\%), and federal (85\%) crime labs. Id.

196 The Obama Administration's Committee on Medicolegal-Death-InvestigationSystem released a report in 2016 concluding that many federal agencies rely on death investigation data to implement federal policy. See EXEC. OfFICE OF THE PRESIDENT \& NAT'L SCI. \& TECH. COUNCIL, supra note 194, at 2. The National Commission on Forensic Science similarly recommended that the Department of Justice create a permanent office of Medicolegal Death Investigation to improve the death investigation system by coordinating support for death investigation systems and improving the quality of those systems across the country. $I d$. at 1 . In addition, the Attorney General should seek funding to modernize existing technologies and recruit and retain forensic pathologists. $I d$. at 2.

${ }^{197}$ In 2011, 55\% of death investigation facilities needed additional equipment or renovations. SCI. WORKING GRP. FOR MEDICOLEGAL-DEATH-INVESTIGATION, Infrastructure COMM., Medicolegal Autopsy Facilities IN THE United States 3 (2011), available at http://www.swgmdi.org/images/iscomrpt3-facilities2011.pdf.

198 See Kelly, supra note 4. 
Texas county in which he died are not in step with the national ideals to which we should hold our death investigators, whether in the death of such an important public figure or a private individual.

The typical structure of governmental branches responsible for death investigations and prosecution are such that they tend to be physically aligned, by being housed in the same offices, and/or outcome-aligned, because they operate under the prosecutorial umbrella. The proximity of death investigator and prosecutor offices can create both overt and discreet conflicts of interest that result in fundamental miscarriages of justice. These examples of conflicts obviously go against traditional notions of justice because they can involve outright collusion between death investigators and prosecutors, or even involve prosecutors serving directly as coroner. These types of situations prevent accurate and fair outcomes, because the conflicts resulting from that result directly harm the families of the victim and reduce the suspect's opportunities for a fair trial. Perhaps even more sinister than these overt conflicts are discreet conflicts that manifest over time through subtle influence and pro-prosecution bias. The physical and organizational proximity of the death investigator and prosecutor offices, combined with the repeated use of death investigative services by prosecutors, may create bias in favor of reaching the government's theory in individual cases. This Article provides examples of particular death investigators who compromised their independence in order to give the prosecution an advantage in multiple cases; without question there are many similar stories that go unreported and undetected. These discreet non-obvious conflicts of interest put defense teams, and thereby defendants, at a substantial disadvantage: death investigators may be more willing to give favorable treatment to prosecutors, or even obscure exculpatory results.

The existing mechanisms designed to alleviate some of these issues, such as evidentiary standards, are constrained by official immunity and prevent the public from holding death investigators and prosecutors accountable. To alleviate conflicts of interest and overcome the shortcomings of the existing constraints, this Article advocates for the creation of a federal agency to create uniformity and to oversee the death investigation system. As part of the agency's role, death investigators would be subject to uniform education and training requirements, and death investigators and their laboratories would be required to meet certain accreditation and certification standards to ensure that the actors are qualified. In addition, through accreditation or other means, death investigator offices need to be truly independent from prosecutor offices. Whether this means physically separating the two or providing defense teams with equal access to resources, the current system favors prosecutors too heavily. Finally, as much as possible, the agency should oversee the elimination of the coroner system. Outdated and out-of-touch, the coroner system simply does not have the same capabilities as the medical examiner system. It is possible that elected coroners may be qualified, but too often they are not, and it is the victims and defendants who suffer. 
Perhaps the problem is lack of political will, or funding, or inertia, but the patchwork of systems across the country prevents true justice from being done. A federal system would provide greater resources to struggling systems and ensure uniform death investigations across the country. Without meaningful change, the current system that creates conflicts of interest will continue to thwart the accuracy and integrity of the death investigation process and fairness in individual cases. 
